\title{
The 2010 Hulu Selangor by-election in Malaysia: A Qualitative Analysis
}

\author{
Shahidah Abdul Razak ${ }^{\mathbf{*}}$, Ariff Aizuddin Azlan², Hazariah Yais Razali \\ 1Fakulti Sains Pentadbiran dan Pengajian Polisi, Universiti Teknologi MARA (UiTM), Malaysia. \\ Email: shahidah056@uitm.edu.my \\ ${ }^{2}$ Fakulti Sains Pentadbiran dan Pengajian Polisi, Universiti Teknologi MARA (UiTM), Malaysia. \\ Email: ariffaizuddin@uitm.edu.my \\ ${ }^{3}$ Fakulti Sains Pentadbiran dan Pengajian Polisi, Universiti Teknologi MARA (UiTM), Malaysia. \\ Email: hazariah387@uitm.edu.my
}

\section{CORRESPONDING}

AUTHOR (*):

Shahidah Abdul Razak

(shahidah056@uitm.edu.my)

\section{KEYWORDS:}

Hulu Selangor

By-election

Authoritarian

Barisan Nasional

Pakatan Rakyat

Opposition

\section{CITATION:}

Shahidah Abdul Razak, Ariff Aizuddin Azlan, Hazariah Yais Razali. (2022). The 2010

Hulu Selangor by-election in Malaysia: A Qualitative Analysis. Malaysian Journal of Social Sciences and Humanities (MJSSH), $7(2), \mathrm{e} 001259$.

https://doi.org/10.47405/mjssh.v7i2.1259

\begin{abstract}
The ruling Barisan Nasional (BN) for the first time failed to secure its two thirds majority in Malaysia's 2008 general elections and lost few states to the opposition Pakatan Rakyat coalition parties. This indicated that, the opposition parties successfully posed credible challenges towards the authoritarian regime. In 2010, the ruling Barisan Nasional was tested once again, when Hulu Selangor by-election was held. By using the qualitative content analysis as the research methodology and the framework for analysis, this study examined the factors that affected the performance of opposition Pakatan Rakyat in the 2010 Hulu Selangor byelection. The significant of using this particular method is that, it contributes towards the understanding of the dynamic competitive election within the context of Hulu Selangor by-election. İt could be argued that, the ruling Barisan Nasional managed to bypass the opposition Pakatan Rakyat by utilizing its strategy of political development. Beside that, the proposed methodology of qualitative method of analysis also revealed a number of factors such as: the candidates, electoral issues, and campaign strategies.
\end{abstract}

Contribution/Originality: This study contributes in the existing literature on the Hulu Selangor by-election and it uses the methodology of qualitative content analysis and it is one of very few studies which have investigated the performance of competing political parties particularly within the context of authoritarian setting.

\section{Introduction}

In most advanced democratic countries, the conduct of by-elections is an integral part in the embedded political systems. According to Norris (1990), by-elections are often seen as the most transient phenomena. To a certain extent, the phenomena of by elections are also an ephemeral subject which does not affect much of the political system. It was further argued that, whether the by-elections could provide a significant point in terms 
of its conducts and the answer provided was 'Yes' for the party occupying the seat. The advent of by-elections in this sense has more or less the proclivity of affection towards the rest of significant political institutions such as: the Parliament, Ministry Cabinets, and so on. In the words of Feigert and Norris (1990), by-elections are widely used to fill in legislative seats that were declared vacant between regular elections. Meaning to say that, there is an obvious difference between the conduct of general elections and byelections. The general elections are conducted based on stipulated laws inherited by the framework of political system. As for the by-elections, the advent of its conducts is unpredictable due to some sort of inevitable causes like death, found guilty by the court of law, self-resignation from the seat and many more that would contribute towards the vacant of seats.

As further argued by Feigert and Norris (1990), they stated that, the by-elections could be understood in terms of its significance, based on several premises that, the main purpose of by-elections is beyond the obvious reason of filling vacant legislative seats. Therefore, the conduct of by-elections could create some sort of serious implications for the legislature, political parties, electoral campaigns, governance and the media. These are considered as the most benefitted variables besides the voters who cast their votes. As argued by Hakim (1994), the conduct of by-election within the context of parliamentary systems is often treated as a barometer for testing an incumbent government's degree of popularity. This is indeed true and palatable in the sense that, the ruling majority party could always sense an electoral threat, if the seats are inevitably vacant. In the case of Malaysia, it has proven something else. The post-2008 general elections was marked as the most flaunting of by-electoral competition between the ruling BN government and the newly formed opposition party Pakatan Rakyat. Altogether, a total of sixteen by-elections were held after the 2008 Malaysia's general elections and soon after the 12th Parliament was reconvened. These by-elections included parliamentary and state legislative (DUN) as well. Therefore, this study attempts to analyze Hulu Selangor Parliamentary by-election in the state of Selangor, by particularly looking at the factors that affected the performance of Pakatan Rakyat.

\section{Research Methodology}

This is a qualitative descriptive study. According to Berg (2001), qualitative research properly seeks answers to questions by examining various social settings and the individuals, who inhibit these settings. In addition, qualitative researchers are also more interested in how human arrange themselves and their settings. Besides that, this study will be looking at the phenomena of Hulu Selangor by-election by using the approach of 'content analysis'. Content analysis as a research technique is frequently used among qualitative researchers. According to Krippendorff (2013), content analysis is defined as a research technique for making replicable and valid inferences from texts to the contexts of their usage. This statement is supported by Mason (2002) where she argued that, the primary aim of qualitative research was the production of rounded and contextual understanding on the basis of detailed data.

It has been argued that, the proper methodology for this study is the qualitative style of approach. Since the proposed subject matter is electoral politics, and it is one of the subfields in political science, and therefore, it is asserted that the underlying phenomenon could be assessed through the qualitative method. As McNabb (2010) argued, understanding towards the actions of people under social circumstances could be realized through the interpretive research. Thus, this serves the purpose of political 
science research that leads to the explanation and exploration of some phenomenon. As argued by Romeo (2011), blogs were part of examples of new communication and this has become a veritable social showcase. It indicates that, the use of blogs in the field of research has become prominent. The idea of promoting the usage of blogs is probably due to its embedded nature such as political, intellectuals, comical, while some are focused on a specific topic, and eccentric. In this study, blogs are treated as part of qualitative sources, where most parliamentarians do have their own blogs. Blogs are also utilized by the parliamentarians as a social platform where some of their thoughts are shared in the blogs so that, the readers will get to know parliamentarians intention and position upon certain issues.

When it comes to newspapers, Waldman (2004) opined that, the researchers had long employed newspapers as a unique source of information and it has been used for biographical research and the same time it offers a wealth of first-hand information. Surely it decisively suggested that, the newspapers had the tendency to record all the events that happened, while the future is remaining unknown. This study would utilize the newspapers as part of primary sources. Besides official documents recorded by the governmental agencies, the newspapers can also be crucial since it records most of the social and political actions around us. In supporting the statement, Waldman (2004) further added that, the newspapers provide eyewitness accounts and direct quotations from the participants and it leads to significant primary source documentation for researchers. Besides that, Segall and Schmidt (2006) maintained that, newspapers are never neutral or objective and they are always ideologically positioned and positioning and always embedded in particular ways of seeing and representing the world. Despite of various characteristics of newspapers, it guides us in understanding the social setting as a whole. As for the secondary data (Tosh, 2010; Burke, 1992), this study would heavily depend on books and scholarly articles, which are to be acquired from various educational institutions, such as the libraries of International Islamic University (IIUM), Universiti Kebangsaan Malaysia (UKM), University of Malaya (UM) and the National Library as well as the University flagships journals.

The findings and results of this study are provided in the form of content analysis to facilitate the understanding of political competition in Hulu Selangor by-elections. According to Harrison (2001), a lot of political-related information could be simply found in newspapers and it also contains a vast amount of political data. In Malaysia, some newspapers tend to be partisan and bipartisan. All the newspapers, report political phenomenon in form of events, speeches, and many more. Harrison also argued that, the approach of 'substantive content analysis' could be utilized in unfolding the political events, reported in the newspapers and therefore. the primary findings of this study would be derived from the extensive use of newspapers as part of the existing sources of political data (Harrison, 2001). Hulu Selangor was a parliamentary constituency located in the state of Selangor. In the 2008 general elections, the opposition PKR safely regained the constituency from the grip of the ruling BN government. P94 Hulu Selangor parliamentary constituency is made up of three different state constituencies such as: N5 Ulu Bernam, N6 Kuala Kubu Bahru, and N7 Batang Kali. In the state of Selangor also, the ruling BN government for the first time in its electoral history had met a tremendous lost to the opposition in the 2008 general elections. Provided with a strong majority in the DUN, the opposition political parties (PKR, DAP, and PAS) managed to form a state government. 


\section{The Context}

Hulu Selangor by-election was proven to be a turning point for the ruling BN government, where they had regained the seat and for the opposition PR, it was clearly an indication that, the status quo was not fated to be maintained. The by-election was held soon after Najib Razak celebrated his first anniversary as the PM of Malaysia, with his strong politically attached. In addition, some of unresolved issues were further made available by the opposition parties to utilize them as points of campaign in delivering the message to the public. Since the new PM assumed the office, the marketization of the "1 Malaysia" concepts was aggressively highlighted throughout the country.

People-based polices were announced and distributed. In the name of one Malaysia and was also proclaimed that, the sense of communal was not part of national agenda as believed. The main purpose of putting aside the race factor was to mend the relationship between the non-Malays, as most of their votes went to the opposition parties in the 2008 elections. Especially, the Chinese or the "Chinese Tsunami" as it was experienced this. In the previous by-elections that were held, all the three parliamentary seats were consistently won by the opposition PR, and the ruling BN unexpectedly met its electoral faith. Therefore, Hulu Selangor was marked as the fourth parliamentary by-election held in the post 2008 election. It was perceived that, the calling for the Hulu Selangor beelection had been the utmost political test for Najib leadership with the idea of introducing the reform. Najib was believed to take a hold of the PM position in the midst of unstable economy and political instability.

However, his administration was able to put forth some of key reforms as part of his ideas in transforming Malaysia as a nation. Realizing that, Najib's governmental, and as well as his political performance was getting consolidated. It would be partly difficult for the opposition PR coalitions to catching up with a dynamic structured of mobilization in carrying out a message of reform except for the previous indication of voting behaviour in 2008 elections that brought PR to an almost a definite victory. The Hulu Selangor constituency for most of the time was retained by the ruling BN government and was considered as the safe seat and unfortunately until 2008 general elections, where the seat was lost to PKR candidate. When the by-election was scheduled to be held, a number of different competing parties set their footsteps to engage in an electoral battle. The opposition political parties comprising of PKR, DAP and PAS had remarkable performances within the context of Selangor, where they had successfully secured 36 out of 56 state seats contested (The Election Commission of Malaysia, 2008). Compared to the 2004 elections, the opposition could only obtain two out of 56 seats contested.

Therefore, Hulu Selangor by-election, in a way, had been perceived as another chapter of political test for the PR-led state government in Selangor. Since the ruling BN disastrous electoral performance in Selangor, they have yet to cease from being politically active in regaining the state of Selangor. Clearly, it was also a test for Selangor chief minister Abdul Khalid Ibrahim from PKR party. When Khalid was unanimously agreed and chosen to lead the state of Selangor, there were lots of political predicaments, which were posed to him during his tenure. Khalid also inevitably inherited an old administrative structure from the past UMNO chief minister Mohamad Khir Toyo. Khalid was provided with many of Selangor civil servants, from the private secretary to the district officers, who were still 'loyal' to their boss (Ali, 2010). As analyzed by Keen (2012), it was stated that, the main challenging for the PR state government in Selangor was measured in terms of the federal-state relations. Recently, Malaysia experienced an 
increasing centralization, where the federal government which is the ruling BN had all the voice in determining something above the zest of federalism.

For instance, the PR-led state government attempted to undo what the ruling BN did, when they were in power in Selangor. The PR managed to intercept the BN conduct of privatization upon the water services by taking over all the concession companies, in which PR believed had strong-UMNO relations. This had led to a serious form of political intervention initiated by PR in, which the ruling BN was unlikely preferred to accept. On 25 March 2010, Hulu Selangor MPs Zainal Abidin Ahmad was dead, due to a brain tumor (Malaysiakini, 2010a). The death unfolded a new series of electoral competition that was obviously (inevitable). Anwar's speech in the program of "Gathering to Save Malaysia" at Hulu Selangor stated that, the late Zainal Abidin had long suffered due to the cancer and had undergone three operations before (Malaysiakini, 2010b). Anwar also confirmed that, the Hulu Selangor seat was retained by Zainal but, had been in "dying" condition. The seat was consistently maintained by the ruling BN, but in the 2008 elections, the seat was lost to the PKR and Anwar was of the view that there might be an expected predicament in securing the seat.

\section{Electoral Results}

The Election Commission (EC) in their meeting announced that, the polling day would be on 25 April 2010 and the nomination of candidate would be on 17 April. Hulu Selangor by-election was a direct contest between the ruling BN candidate from MIC and the PR candidate from PKR.

As shown in the Table 1, the ruling BN candidate P. Kamalanathan successfully defeated PKR candidate Zaid Ibrahim with a majority of 1,725 votes. The result indicated that, PR could not have had a grip in maintaining its status quo. Clearly for PKR, the success in Permatang Pauh by-election did not further manifest and Hulu Selangor by-election was marked as the first defeat for PKR and eventually, the PR-led state government in Selangor. Compared to PKR previous performance in the 2008 elections, Zainal Abidin of PKR slightly defeated G. Palanivel of MIC with a narrow majority of 198 votes.

Table 1: The April 2010 Hulu Selangor By-Election Result

\begin{tabular}{llllll}
\hline $\begin{array}{l}\text { Candidate } \\
\text { and Party }\end{array}$ & Votes & Majority & $\begin{array}{l}\text { Spoiled } \\
\text { Votes }\end{array}$ & $\begin{array}{l}\text { Voter } \\
\text { Turnout }\end{array}$ & Electorate \\
\hline $\begin{array}{l}\text { P. } \\
\text { Kamalanathan } \\
\text { (BN-UMNO) }\end{array}$ & 24,997 & 1,725 & 731 & $\begin{array}{l}48,935 \\
(75.87 \%)\end{array}$ & 64,500 \\
$\begin{array}{l}\text { Zaid Ibrahim } \\
\text { (PR-PKR) }\end{array}$ & 23,272 & & & \\
$\begin{array}{l}\text { Breakdown of total voters: Malays (52.70\%), Chinese (26.30\%), Indian (19.30\%), Others } \\
(1.70 \%)\end{array}$ & & & & \\
\hline
\end{tabular}

Source: The Election of Commission Malaysia (2010)

In the 2004 elections, G. Palanivel decisively won the seat by defeating PAS candidate Ismail Kamus with a majority of 14, 483 votes. Unfortunately, the 2008 trend seemed not to be repeated again in the by-election. In Hulu Selangor by-election, P. Kamalanathan of MIC was able to increase the majority of votes pooled. For instance, in 2008 elections, G. Palanivel of MIC managed to obtain a total of 22, 979 votes, but in Hulu Selangor, P. Kamalanathan had obtained a total of 24, 997 votes, while the trend of 
votes had increased to 2, 018 votes. This had probably marked that P. Kamalanathan performed better than his MIC partner G. Palanivel in terms of winning the seat. The ruling BN on the other hand, according to BN secretary-general Tengku Adnan Tengku Mansor' statement that, even though the ruling BN had won with a majority of 1,725 votes, but in the same time they found that the Chinese voters did not support BN candidate (Malaysiakini, 2010c). Not even the Hulu Selangor by-election, but including the 2008 elections as stressed by Tengku Adnan. Based on the statement, it probably indicated that the Chinese voting behaviour was still caught within the 2008 elections mood, and even though, the Chinese voters had made up of 26.30 percent of total electorates, but it still could not change anything until, and unless a shift occurred in Malay voting behaviour.

As for PR, even though they were defeated, but in a way there seemed to be an increase in terms of votes pooled. For instance, when Zainal Abidin of PKR won the seat with a collected of 23, 177 votes, but in the Hulu Selangor by-election when Zaid Ibrahim of PKR was defeated, Zaid could maintain the votes received and in fact it increased to 95 votes. This led to an assumption that PR already established a base of its voters.

\section{Factors That Affected PR Performance}

Obviously the PR coalition parties were defeated by the ruling BN in the Hulu Selangor by-election. The history had proven that, Hulu Selangor parliamentary constituency was traditionally perceived as one of the ruling BN strongest parliamentary "fortress" in the post-Independence (Besar et al., 2011). From 1959 elections, the MCA contested for the Hulu Selangor seat and consistently won until the 1982 elections. After that, started from the 1986 elections, the seat was ceded to the MIC and was steadily maintained until 2004 elections, while lost in 2008. The most interesting point was that, UMNO had never contested the seat even though, it was a Malay-majority constituency and non-Malay based party like MCA and MIC that easily won such Malay-majority constituency. Hulu Selangor, in a way, was marked as the first parliamentary by-election defeat for the opposition PR, especially PKR, within the national political context. Therefore, there were several of considerable factors, that affected the PR performance in the by-election.

\subsection{The Candidate}

During the Selangor BN convention at Shah Alam, PM Najib in his speech announced that, Hulu Selangor seat would go to MIC respectively. When MIC was announced as the party that would field a candidate and thus had ceased all the speculations made on which party would contest the by-election. Due to a concrete confidence that MIC had been granted a green light to field the candidate, there was an attempt made by MIC president S. Samy Vellu, where he had proposed for G. Palanivel to recontest the seat again. Suddenly, the MIC chief of information P. Kamalanathan was announced by the BN deputy-secretary Muhyiddin Yassin as the candidate. Rumours had it that G. Palanivel was rejected by BN top leadership after a negotiation took place but the negotiation was unsuccessful. Based on the previous of by-elections contested by the ruling BN, some of the candidates were of the representative for state constituencies. But in Hulu Selangor, the ruling BN came up with a different thought of candidate selection. Kamalanathan worked as the chief of public relations in Beras Jati, a rice company. Besides that, Kamalanathan was also a blogger and a part-time lecturer in a private college. 
The selection of Kamalanathan as the candidate was perceived as a new approach in facing the PR coalition parties, where the ruling BN indirectly agreed not to field in a candidate, who had contested the Hulu Selangor seat like Palanivel before. According to a well-known Professor of History, Dr. Ramlah Adam, she advised the ruling BN component parties to avoid fielding in a "problematic candidate" in the by-election and further justified that, the candidate factor would answer all questions (Malaysiakini, 2010d). It was made clear that, the ruling BN did not pick up Palanivel as the by-election candidate, even though, he had his first lost in the 2008 elections. Also, the same time the ruling BN was of the idea of paving way for new face to contest. Kamalanathan also possessed none of past electoral records and except that, he was expected to contest on the grounds that, he was a member of MIC party as the chief of information.

Even though, Kamalanathan was a new face candidate provided without having any remarkable electoral records. It was initially perceived that he might face a difficult task in reaching out to the voters, but the by-election result prove something else. As for the opposition PR, after having a coalition consensus, they agreed to field in a candidate from PKR (Malaysiakini, 2010e). The PR unanimous decision indicated that, they had observed the previous of status quo, where PKR candidate contested the 2008 elections and even though, PAS once contested the seat in 2004, but the opposition PR had agreed to maintain PKR as the by-election candidate, due to PKR's success story in Hulu Selangor in 2008 elections.

According to PR leader Anwar Ibrahim, the candidate would contest under the umbrella of PR. Finally, several days before the nomination of candidates was held, Zaid Ibrahim was announced by Anwar as PKR candidate to contest the by-election. Zaid was a former cabinet minister during the reign of Abdullah Ahmad Badawi before he quitted UMNO in 2008 and joined PKR, due to the sign of protest upon the detention of Teresa Kok of DAP from Seputeh parliamentary constituency under the ISA. Provided with his remarkable legal skill as a lawyer and past ministerial experiences, he was seen as electorally fit to contest for the by-election, due to the said resume. Besides that, Zaid also possessed a legal firm known as Zaid \& Company (Zico), which was regarded as the largest legal firm in Malaysia. In terms of past electoral records, Zaid used to be BN MPs for Kota Bahru parliamentary constituency in the state of Kelantan in the 2004 elections.

Soon after Zaid was made known as PR candidate, the ruling BN immediately claimed that, Zaid was an outsider from Kelantan and new to his party (Malaysiakini, 2010f). According to the former Selangor chief minister Mohd Khir Toyo, the selection of Zaid as the candidate would provide an advantage for the ruling BN to survive the by-election. In most of elections held in Malaysia, the candidate would be preferred as someone who was a local and had a particular attachment, such as the place of born or growing up, to his or her hometown for the purpose of getting know well in the constituency. But PKR strategy in fielding Zaid was seen as misnomer and did not fit the criteria as a "Local" and therefore invited criticisms from the ruling BN to simply accuse that the opposition PR did not represent by the local candidate.

Besides that, Zaid was also criticized of being a rich and was challenged to declare his property by the deputy PM Muhyiddin Yassin (Malaysiakini, 2010g). But Zaid immediately denied the allegation and the same time pointed out the challenge of declaring the property to Muhyiddin. Based on that initial allegation, Zaid's image as PR candidate would probably be tarnished and surrounded by controversies. In a research conducted by a team of academics, it was found that, 59.0 percent of respondents in 
Hulu Selangor opted for "honest and trustworthiness" criteria of candidate (Besar et al., 2011). With such allegation made by the ruling BN, it would be hard for Zaid to convince the voters to vote for him. The allegation was also seen as an attempt to widen Zaid's political loopholes, and later on manifested during the campaign period.

\subsection{The Issues}

The Hulu Selangor by-election was definitely characterized by some of debated issues that became an electoral basis for both of competing parties. During the early period of campaign, that day was covered by an incident initiated by party's supporters. It was reported that, according to PR coordinator officer for Hulu Selangor Ali Rahman, the incident sparked, when the BN youth was seen as throwing a bottle full of water towards audiences who was going to attend PR ceramah. It was further claimed to be a provocative action by party's supporters and the police squad immediately came and dispersed the crowds.

On the other hand, PR's image of candidate was tremendously highlighted by the ruling BN, when Zaid was alleged of an "alcoholic", womanizer, and gambler. The allegation of Zaid's drinking an alcohol became part of dominated topics and the issue was strongly circulated among the electorates. A banner with the picture of him drinking an alcohol was also made available in some of strategic locations. Such attack, in a way, had indirectly pointed towards the image of PR as presenting a person who had a tarnished image, due to the number of wrongdoings that could jeopardize political career but what was found out had against the allegation made. And finally, after being attacked personally by the ruling BN supporters, Zaid stood up and confessed to the public by stating that, the drinking habit was an old story and had repented to God for that particular mistake (Malaysiakini, 2010h). The issue was made central due to the conduct of several unknown blogs, who portrayed him as an "drunkard". Therefore, such confession was probably made to silence further the allegations could be made against him. In mitigating the tense ambience, PAS immediately came to the defense of Zaid's alcohol issue. According to PAS secretary of general Mustafa Ali boldly claimed that, all prime ministers in Malaysia had drank alcohol except Abdullah Ahmad Badawi (Malaysiakini, 2010i). Such allegation was made based on Mustafa's own experience when he used to be part of government a long time ago and thus, he issued a serious warning to those who were responsible for bringing up Zahid's alcoholic issue not to politicize the issue, as some of the top leaders in BN also did the same thing Zahid was alleged.

Besides that, another serious issue which was reported concerning the action of EC in moving out a total of 13, 488 registered voters to another polling station. According to PKR director of Hulu Selangor by-election Fuziah Salleh, it was the EC's strategy to topple down the PR coalition parties. Besides that, as stressed by Fuziah, the same thing happened in Selangor in 2004 elections. The issue was seriously taken up by the opposition PR as they believed that, the transfer of voters would jeopardize their electoral performance, if the EC was really behind the matter. Fuziah also claimed that, about 230 PR strong supporters in Kampung Tanjong, Sungai Cho had switched to another constituency.

Realizing that the situation was getting serious, PKR asked the voters to search for their new polling station directly from PR operation centres for the purpose of tracing back the voters who are misplaced. Eventually, the EC came forth to defend the allegation by 
clarifying that, the adjustment of transferring the voters had been carried out, since before the Hulu Selangor by-election was schedule to be held (Malaysiakini, 2010j). On top of that, Fuziah Salleh who was also MPs for Kuantan parliamentary constituency proposed the motion concerning the EC action into the Parliament (Malaysiakini, 2010k). Unfortunately, the Speaker of Parliament rejected Fuziah's request on the ground that, the matter was political (Parliamentary Debates, 2010). The Speaker further clarified that, the matter was not necessary to be debated in the Parliament, while Fuziah envisaged that thousands of voters would be lost during the by-election day, due to the unknown polling station which was recently shuffled. In this manner, the opposition PR was beyond the reach, where PKR, for instance, had utilized other official means which was the Parliament and was hoped that the EC matter would be agreed for the debate purpose at the same time to resolve the controversial issue concerning governmental body such as the EC.

Such attempt did not successful and did not gain any political currency outside the byelection context. At the same time, the Coalition for Clean and Fair Elections (BERSIH) claimed that, the EC conduct was "unconstitutional" in terms of transferring voters to other constituency. BERSIH, as a non-profit body that consistently fought for the idea of clean elections found that, the practice was misnomer and was not fit into the democratic zest in the country. According to one of BERSIH top members Ambiga Sreenevasan, such practice was referred to as an "electoral delineation" and based on what the EC had done, it would affect the voters to become "disenfranchised". Therefore, a representative sent from the Research for Social Advancement (REFSA), Richard Yeoh, suggested to the PR-led state government in Selangor to assist the voters to get to the polling station in time by providing buses. Based on a singular issue involving the public authority, it was discovered that the responses were widely gained including the NGOs and also political parties. In a way, this had given the ruling BN parties, a better chance to mobilize (put) forwards and politicized each and every issue brought up to support their by-election.

The campaign mood was further intensified, when the former chief of KeADILan youth Ezam Mohd Noor in a press conference in Hulu Selangor claimed that, Anwar Ibrahim had a relationship with the Israel. Besides Zaid, Anwar were among the political figures that secured an electoral attention, during the campaign period. Most of the issues were politicized at the same time, a point of reference was made to Anwar for the purpose that, his political image would be seen as "unacceptable" by the public. Ezam, who used to work with Anwar before he was ousted from the government, had turned his back on Anwar due to political reasons.

Ezam claimed that, all evidences that related to Anwar's links with the Israel had been collected and would be distributed to all MPs in the Parliament. Contrary to that, in the Parliament, Tian Chua of PKR proposed a motion to insist that government should drop the agreement made with the APCO Worldwide as it would jeopardize the national security. Unfortunately, the motion was rejected on the grounds that it was not a public interest (Parliamentary Debates, 2010). The opposition PR believed that, the controversial media consultant APCO was an Israeli-based company that the government currently has her hand on it. The attempt to debate the APCO issues in the Parliament led to an impasse and PR had resorted to sensationalize the issue during the campaign period. In relation to this, it was reported that, a number of banners was found saying that the PM Najib would join a national debate in Kuala Kubu Baru together with 
Anwar to discuss several issues such as, national security and the Israel (Malaysiakini, 2010l).

In contrast, the debate was scheduled to be attended by some of PR top leaders in delivering a ceramah. Also, Najib was reported to be in a different place, at the same time as stipulated in the banner, as to assist BN candidates. The existence of the banner was mysterious and no one so far had claimed to be responsible for such conduct. PAS was of no exclusion in terms of political attacks that targeted its leader. Kelantan chief minister Nik Abdul Aziz Nik Mat was forbidden in delivering a religious sermon or ceramah in each of the mosques in Selangor. According to the director of Selangor Department of Islamic Religious (JAIS) Muhammed Khusrin Munawi, the order was not pointed to Nik Aziz alone, but it encompassed all people (Malaysiakini, 2010m).

The issue broke out when Nik Aziz was suspected of delivering his speech in one of the mosques in Hulu Selangor during the campaign period. As one of the gigantic political figures from PAS, the present of Nik Aziz in the campaign was expected to attract more PR supporters, but when Nik Aziz delivered his sermon in the mosque, his action was politically (Motivated) attached. To a certain extent, this led to a statement issued by Selangor Sultan Sharafuddin Idris Shah by urging the police to take action upon people who utilized mosques as a campaign platform in Hulu Selangor by-election. The occasion was quite rare, where the Religious Chief of State directly admonished some matters related to local politics, especially within the context of Hulu Selangor by-election. JAIS further clarified that only people who were granted a tauliah or a permission to deliver a religious speech and could use the mosque. The PM Najib described the action of Nik Aziz as a serious defiance upon the royal institution. An the same time, the opposition PR was also blamed for disrespecting the Federal Constitution and some matters regarding Islam. Clearly, it was a strong message that the opposition PR conduct was observed and their mobilization was limited, due to a limited governmental access that the ruling BN enjoyed most of the time, especially during the election seasons.

\subsection{A Unified Opposition Strategy}

The calling for the Hulu Selangor by-election had geared up the heat of the opposition PR in mobilizing throughout the campaign period for the purpose of getting as much supporters as they could. Based on the previous parliamentary by-elections, the opposition PR had employed a successful strategy of a unified coalition, where they remarkably performed and won those by-elections.

Unfortunately, Hulu Selangor was not part of PR success story of by-election contests. At first and had been conducted in the previous by-elections held, the opposition PR mainly put forth its mobilization effort, based on the nomenclature of the oppositional unity to rally mass supports from the public. In the case of Hulu Selangor, the opposition PR had earlier initiated its campaign before the nomination of candidates happened (took place). PR campaign was themed "the campaign to save the country" and was launched in the Mini Stadium Kuala Kubu Bharu and it was estimated that some of 5, 000 supporters attended the ceremony (Malaysiakini, 2010n).

Several PR leaders seen such as: Anwar Ibrahim (Permatang Pauh MPs), Selangor chief minister Khalid Ibrahim, PKR deputy-president Syed Husin Ali, PKR vice-president Azmin Ali (Gombak MPs), PKR chief of strategy Tian Chua (Batu MPs), PAS member of central committee Dr. Hatta Ramli (Kuala Krai MPs), and Lau Wen Sang (Kampung 
Tungku state representative) were spotted. The present of these PR political figures were expected to rally as much as they could for the by-election and many of messages were delivered to the PR supporters. One a one hand, Hulu Selangor was a parliamentary constituency that located in Selangor and practically, it was a state government governed by the PR parties and therefore would be expected to produce a remarkable performance. During the ceramah, Azmin delivered a record of Selangor's achievements for the past two years of administration. According to Azmin, PR state government in Selangor brought in an investment worth of RM7 billion within two years and in 2009 alone, the state government provided a job opportunity to 20, 753 people. Based on the information given, this would give an extra advantage to PR electoral performance in which, they could sustain their supporters mainly from Selangor, due to what the PR had achieved in terms of state administration.

It was also seen that PR would utilize the positive performance of Selangor state government in countering the ruling $\mathrm{BN}$ for what they did, when they were in power in Selangor. In a visit to the constituency, the chief minister Abdul Khalid announced in his speech that, the achievement of PR-led government in Selangor had resulted into the giving of 20 cubic centimeter of free water and also the donation of RM2, 500 to each of Selangor citizen families who had died (Malaysiakini, 2010o). Besides that, Abdul Khalid warned that, if BN won the by-election, water tariff would likely to be increased and the people of Selangor would be in a trouble. Based on his capacity as the PR state leader, Abdul Khalid gave a word that, the state government would do anything to protect the water concessions from being manipulated by the ruling BN government. The opposition PR further penetrated Hulu Selangor constituency and this time in a ceramah, Anwar raised the question of the purchase of submarine by the government.

The purchase was believed to involve Najib led-government and also the French government. The controversial submarine purchase caught the public attention and it was politicized again in the by-election campaign as part of a strategy to spark the public consciousness regarding the issue. The opposition PR immensely took this matter seriously as it involved billions of funds, which were believed to be mismanaged due to the submarine purchase engineered by Najib, when he was a defense minister. Therefore, the opposition PR distributed leaflets to the voters containing information of the submarine scandal and many other government hidden scandals. The campaign was further strengthened when PAS mobilized its members in (Electioneering campaign) reaching out to the voters.

And the same time, PAS justified that, the alcoholic behaviour of Zaid was a past story and it was not an issue for PAS not to supporting him. PAS chief of operation room Saharudin Ismail stated that 300 PAS supporters from Shah Alam caeme to assist PKR candidate in the by-election. On the other hand, PAS chief of youth Nasrudin Hassan claimed that, he would make sure the effectiveness of PAS electoral machinery in terms of delivering program and disseminating information. PAS systematically designed its form of assistance, where its electoral machinery was imported from outside Selangor and it was done gradually. Billboards posted with the image of PAS spiritual leader Nik Aziz praying for Zaid victory was also hanged in a few of strategic locations. It seemed that, PAS had fully utilized its electoral machinery, based on its capacity as PR coalition partner. As the leading coalition in the state government, PR took an opportunity in the by-election campaign to introduce its manifestos. There are several things that were promising to the electorates, for instance, the giving of land ownership to 10,000 families, the welfare for 73 old men, RM1 million to 40 Chinese schools, the giving of $4 \frac{1 / 4}{4}$ 
acre of lands to the Tamil schools, and the exemption of door tax for unused buildings (Pakatan Rakyat Manifesto, 2010).

Obviously, it was all within the power of PR state government to granting those things to the electorates. However, it was incomparable when it came to the ruling BN parties in terms of promises and the deliveries due to its full access to resources. Few days before the polling, the opposition PR had a minor change in its electoral strategy. According to PKR official, party's supporters and campaign workers were asked to spread as far as they could instead of attending the political sermon (ceramahs). The reason behind was the geographical factor of the constituency. Hulu Selangor was considered a quite big constituency with thousands of electorates. Compared to previous by-elections that were held, people attending the ceramahs were so many but in Hulu Selangor, not so much crowds could be pulled, based on the constituency geographical factor.

It would be difficult for people to attend ceramah when their houses were quite far from the ceramah location and instead of organizing political ceramah, the opposition PR decided to go and meet the voters face to face. Due to this situation, PAS increased their manpower from 2,000 at the early day of campaign to 7,000 few days before the polling. PAS referred to such strategy as "from heart to heart" approach in the campaign with only three days left. Houses were visited by PAS campaign workers and according to them, such move was quite effective and during the visitation, they enlighten the voters, the significance of sending Zaid to the Parliament if Zaid secured the by-election.

As claimed by a PAS member, campaign substances were provided by PKR because the candidate came from its party. Those substances included leaflets, banners, and posters and was all managed by PKR and PAS contributed the Harakah newspaper as an additional substance. PKR on the other hand pleaded with the voters from outside Selangor to come back home. This was written in the banner by PKR saying "do not forget to come back and cast your votes".

On top of that, PKR also provided a gentle reminder stating that, if voters did not come back home, PKR would likely lose the by-election, and the reminder was particularly aimed at the youth. According to PKR chief of information Lee Khai Loon, ten percent out of 64,500 registered voters worked and lived outside the constituency. And based on face to face session with the voters, PKR found that, in 100 houses visited, ten families had sons who either worked or lived elsewhere. Additionally, PKR had utilized other campaign means, for instance, the facebooks, blogs, twitter, and internet video, in achieving the goal of persuading young voters to come back home. The DAP campaign coordinator Lau Weng San also assisted PKR by posting an advertisement in the newspapers that convince the young voters to come back. Besides young voters, the opposition PR also approached the Orang Asli, an aborigine group. It was probably argued that, even though, their numbers were not significant compared to the Malay and the Chinese, but they could still make a political change. Some of PR members temporarily lived together with the Orang Asli as part of campaign strategies and also to convince them to vote for PKR candidate. As being reported by a local media, the opposition PR strengthened their campaign by putting forth Nik Aziz in a series of ceramah to rally the supports few days before the polling. Unfortunately, the expectation of Nik Aziz pulling large crowds turned sour, when Nik Aziz had inaugurated the Convention of FELDA Sons and it was a total of 400 people who came at Sungai Tengi (Malaysiakini, 2010p). 
Randomly, the voters around there claimed that Nik Aziz failed to play a decisive role in attracting more crowds that could be expected. In a way, Nik Aziz's presence was to save PKR candidate from being personally attacked by the ruling UMNO. According to PAS director of research Wan Abdul Rahman, in the campaign, Nik Aziz was totally needed for the purpose of answering all allegations pointed to Zaid. By having the all-rounded figure who was also well-versed with the knowledge of Islam, it was argued that, Nik Aziz gradually reduced Zaid's burden in facing unwarranted allegations launched by the ruling BN.

Another new appearance that struck the electoral ambience was the presence of Tamrin Baba during the opposition PR ceramah. Tamrin was a son to a former deputy prime minister Ghafar Baba during the reign of Mahathir. Even though, Tamrin did not speak in the ceramah, but the opposition PR fully utilized the chance especially, when Anwar praised him in front of crowd. Such action indicated that UMNO members who opted to leave the party must have had something that caused them a trouble before they could resort to that particular action (solution). Probably, it was carried out for a particular purpose of convincing the crowds that most of the ruling $\mathrm{BN}$ members turned to opposition PR literally. Based on PR mobilization, the campaign session was systematically carried out, but it did not yield a good result. Zaid was defeated with a margin of 1,725 votes. Even though, the opposition PR campaign strategy could not secure the electoral result, but in a way, PR mobilization at least maintained the total votes garnered by Zaid and as well as votes secured by the previous incumbent Zainal Abidin in the 2008 elections. This led to an assumption that, the opposition PR had never lost its electoral base in Hulu Selangor constituency, based on the results secured by Zaid.

\subsection{BN Campaign Strategy}

As stated earlier, the Hulu Selangor by-election was held soon after the PM Najib celebrated his first anniversary of becoming the sixth PM in Malaysia and his administration perpetuated the political grip of semi-authoritarianism in Malaysia. Hulu Selangor by-election was also the first of BN's success in a series of parliamentary byelections held in the post-2008 elections. Even though, the ruling BN regained the seat and also to turn down the previous status quo in which had been maintained by PR. it deserved an elaboration on BN campaign strategy as part of factors that affected the opposition PR within the context of Hulu Selangor by-election.

In the early month of April, the deputy Prime Minister Muhyiddin Yassin stated that, Hulu Selangor constituency promised four new schools, even though, he stressed that he was not in the mood of campaign (Malaysiakini, 2010q). The announcement was made at the school in Hulu Selangor and after that, he left for Batang Kali and announced the allocation of RM2 million to prevent the problem of flooding in the village. The Department of Works (JKR) was asked to complete the task immediately as ordered by the UMNO deputy president. And the same time, he approved the application of AlSajdin mosque to get an ambulance to carry a corpse and a place of performing an ablution for women worth of RM100, 000. As claimed by Muhyiddin, it was not part of campaign but practically, it had been done in the previous by-elections held, but in the name of development, where promises were delivered and people were given an electoral guarantee to get what they had been waited for quite some time. 
Muhyiddin's visitation to Hulu Selangor was criticized by PKR member Shamsul Iskandar, where he clarified that, such action was obviously an act of an excessive political bribery due to the promises delivered (Malaysiakini, 2010r). Clearly, Hulu Selangor was a kicked-off for the developmental strategy initiated by the ruling BN component parties. Besides that, there was a voice from the people of Kampung Sungai Buaya demanding that, the well-being of the village was to be put into consideration by the ruling $\mathrm{BN}$, and suddenly the request was granted. The village received a new allocation and it was approved by BN coordinator for Hulu Selangor constituency G. Palanivel. Many of the development projects concerning the upgrading of the village infrastructure were of the ruling BN central concerns. Millions of allocations were announced and approved.

The idea of disclosing such a big amount of allocation was to convince the electorates that, the ruling BN could provide anything that could benefit the citizens in terms of finance and material things. The ruling BN component parties had geared up to the fullest, in an attempt to regain the traditional seat that they had consistently won until the 2008 election. Hulu Selangor was considered a rural-based parliamentary constituency. Even though, the constituency was within the jurisdiction of PR state government in Selangor, but based on its status as the rural-based and therefore the ruling BN had a considerable chance of getting back what was lost. On the other hand, the MIC chief of women P. Komaladevi mobilized BN party workers to visit from house to house for the purpose of solving the issue of citizenship challenges for those who were holding the red identity card. Based on the feedback received, some of the families were thankful due to the calling of the by-election where their challenges were immediately solved.

In the campaign, the ruling $\mathrm{BN}$ had publicly disclosed its potential manifesto, for instance, RM2 million project of solving flooding challenges, the construction of four type of schools, RM32 million for the housing project of FELDA settlers, RM10.2 million for house maintenance, RM100, 000 for upgrading the mosque, RM1, 000 for each of FELDA settlers who would like to become an entrepreneur, and the additional of RM2.1 million for repairing seven houses (Barisan Nasional Manifesto, 2010). The ruling BN was aggressively all out in winning the heart of electorates. Millions had been spent during the campaign, and such amount would probably contribute an impact for the opposition PR in the electoral race, as PR would be in a difficult state to generate such amount. On the other occasion, the ruling BN campaign was attended by the former longest-serving Prime Minister Dr. Mahathir Mohammad.

Mahathir's present was perceived as a counter-campaign to the PR as PR also invited some of well-known political figures who used to be with UMNO. Interestingly, during the campaign, the wife of PM Rosmah Mansor was reportedly campaigning for BN candidate P. Kamalanathan. Among the places that were visited were the FELDA area, where the BN machineries, together with Rosmah appealed to the settlers to vote for BN candidate. And the same time, Rosmah gave RM1, 000 to each of the communities to fund their training programs.

When the opposition PR delivered the performance of Selangor state government to the electorates, the ruling BN stated otherwise. In the campaign, according to the President of MCA Dr. Chua Soi Lek, PR-led state government had failed in terms of promises given to the electorate. It was further stressed that, the people in Selangor would like to know what kind of change the PR had brought into the area. It was perceived that, Hulu 
Selangor by-election had become a strategic location as it was within the state of Selangor and Selangor was under the PR and therefore, any intended argument and criticisms may be pointed towards the PR state administrative. Due to this, previous PR administrative records were unearthed, for instance, the MCA claimed that PR had yet fulfill their promises in granting a land to one of the schools in Serendah. Based on the ruling, BN style of convincing the voters, it had finally led to a victory where Kamalanathan was able to score with a remarkable margin of 1,725 votes. In the 2008 elections, PR narrowly won the seat and this led to an assumption that the ruling BN may be able to regain the seat in the by-election. It had been obviously proven that the ruling BN did so.

\subsection{PKR Internal Constraints}

Among the opposition PR, PKR were perceived as vulnerable to become a political victim. For instance, when two out of three state representatives from PKR in Perak opted to leave the party and the situation had paved way for the ruling $\mathrm{BN}$ to come to power as a state government. And in Penang, the former Deputy Chief Minister who was also a state representative from PKR was under pressure to let go of his position, due to the allegation of corruption (Ming, 2010). These were some of examples that clarified the stability of PKR as one of PR coalitions. In the case Hulu Selangor by-election, PKR was failed to maintain the seat where it had once won in the 2008 elections. Even though, the PKR electoral performance indicated that they could maintain the majority of votes obtained and it showed that, they still had a support base. But unfortunately, its internal constraints or challenges were deemed to be part of factors that affected its performance in Hulu Selangor by-election. The crisis began when PKR treasurer for Hulu Selangor division Dr. Halili Rahmat, who was frequently mentioned as the most potential candidate for the by-election had let the party to make a choice as who would contest the bye-election.

At first, it was a normal political gesture for Dr. Halili to act in such a way. Soon after the nomination of candidate was concluded and Zaid was announced by PR as the PKR candidate to contest against P. Kamalanathan of BN, PKR chief of youth for Shah Alam division Nor'isham Manap and his deputy Muhamad Ali Mukhtar immediately left PKR, based on the reason that they were disappointed with the action of PKR leadership in proclaiming Zaid as PR candidate (Malaysiakini, 2010s). They were of the view that, the selection of Zaid, based on his record as a reformation fighter and justice, was still in the state of ambiguous and had yet to be tested. It was further claimed that, it was a betrayal towards the zest of reformation that they had upheld since the 1999. At the same time, it was reported that, an incident of 200 PKR members in Bayan Baru had left the party due to the lost of confidence towards PKR leadership. In retaliation to that, the Penang deputy of chief minister (II), Mansor Othman of PKR, had questioned the incident of 200 members leaving the party. PKR believed that, the people behind the scene was Ismail Mohd Ali who claimed of bringing out 200 PKR members and Ismail had been under the party's disciplinary committee due to his support towards Bayan Baru MPs Zahrain Mohd Hashim who had been criticized PKR leadership.

Clearly, it happened in the midst of by-election campaign and PKR was politically struck with that particular internal crisis involving members who had dissenting voices. To the worse, Dr. Halili had finally declared that, he would quit from PKR (Malaysiakini, 2010t). Based on his past electoral records, Dr. Halili contested for Hulu Selangor seat in 1999 elections and Batang Kali state seat in 2004 elections, but lost in both elections. Even 
though, there was a rumors saying that he would be picked up as a candidate but it did not end well. At the same time, Dr. Halili further voiced out his intention to join UMNO, due to his political disappointment towards PKR. Besides that, in Perak, PKR women chief of information Soraya Sulaiman and PKR deputy of chief for Bagan Serai division Roshanita Mohd Bashir boldly announced their leaving the party (Malaysiakini, 2010u). Both of them were of the reasons that, they were dissatisfied with the party's management and also Anwar's style of leadership who had determined the party's direction individually. In the Hulu Selangor by-election, PKR was frequently seen as the most opposition party who took the hit enormously from the ruling BN, when they put forth Zaid as their candidate. Zaid was a new member in PKR and he was suddenly picked up as a candidate and this had led to PKR internal impasse. Personality attack upon Zahid was meant to PKR as well. In this case, Anwar as the de facto PR leader had to undergo all the criticisms made to his party. Several months after the by-election, a story suddenly broke out and Anwar publicly smashed Zaid due to his problematic behaviour in the party. Anwar openly claimed that, Zaid was free to leave the party and Zaid was also the one who requested to be the candidate for Hulu Selangor by-election, even though, such decision had met a strong objection from the grassroots supporters. In a nutshell, the idea of installing Zaid as the by-election candidate had led to a several outcomes that the opposition PR, especially PKR would have to look profoundly.

\section{Conclusion}

The result of 2010 Hulu Selangor by-election qualitatively indicated that, the ruling authoritarian Barisan Nasional was still gaining the momentum and enjoyed a popular support. Besides that, based on the data analysis presented above, it is argued that, the performance of opposition Pakatan Rakyat in the by-election was limited due to a number of strategies employed by the ruling Barisan Nasional. The strategy of political development was obviously utilized by Barisan Nasional for the purpose of undermining the opposition parties. Not only that, one of the critical factors that led to the consolidation of Barisan Nasional in the by-election was PKR's internal crisis and when the crisis was not able to be contained, and thus it was easy for Barisan Nasional to make a way in the by-election. Therefore, it could be summed up that the qualitative content analysis in which was used in this study had revealed the idea of competitive elections and also some of the major factors that affected the performance of the opposition parties in the by-election. The significant of qualitative method of analysis is integral in this part of study and the results are discovered in the way the data was analyzed.

\section{Acknowledgement}

Part of this article was extracted from a doctoral thesis submitted to University of Malaya, Kuala Lumpur.

\section{Funding}

This study received no funding.

\section{Conflict of Interests}

The authors declare no conflict of interest in this study. 


\section{References}

Ali, S.H. (2010). Political and Administrative Challenges for Selangor in The Road To Reform: Pakatan Rakyat in Selangor, ed. Tricia Yeoh, T. Petaling Jaya: SIRD, 87.

Barisan Nasional Manifesto in Hulu Selangor By-Election. (2010).

Berg, B. (2001). Qualitative Research Methods for the Social Sciences. Boston: Allyn \& Bacon.

Besar, J. A. et al. (2011). Kajian Budaya Politik Melayu Dalam Pilihan Raya Kecil Hulu Selango. Jurnal Melayu, 8, 153-172.

Burke, P. (1992). New Perspectives on Historical Writing. Pennsylvania: Pennsylvania State University Press.

Feigert, F.B. \& Norris, P. (1990). Do By-Elections Constitute Referenda? A Four-Country Comparison. Legislative Studies Quarterly, 15(2), 183-200.

Hakim, M.A. (1994). The Mirpur Parliamentary By-Election in Bangladesh. Asian Survey, 34(8), 738-747.

Harrison, L. (2001). Political Research: An Introduction. Routledge: London.

Keen, K.L.Y. (2012). The Future of Pakatan Rakyat: Lessons from Selangor. Puchong: Vinlin Press.

Krippendorff, K. (2013). Content Analysis: An Introduction to Its Methodology. California: SAGE.

Malaysiakini. (2010a). MP Hulu Selangor meninggal dunia. Malaysiakini, March 25. Retrieved from: https://www.malaysiakini.com/news/127514

Malaysiakini. (2010b). Pakatan akui sukar pertahankan Hulu Selangor. Malaysiakini, March 27. Retrieved from: https://www.malaysiakini.com/news/127651

Malaysiakini. (2010c). BN menang tapi hilang sokongan Cina. Malaysiakini, April 26. Retrieved from: https://www.malaysiakini.com/news/130208

Malaysiakini. (2010d). Elak calon bermasalah bertanding di Hulu Selangor. Malaysiakini, April $7 . \quad$ Retrieved from: http://lib.perdana.org.my/PLF/Malaysiakini_selection/Malaysiakini/10/128537.p df

Malaysiakini. (2010e). Pakatan Rakyat serah Hulu Selangor kepada PKR. Malaysiakini, March 31. Retrieved from: https://www.malaysiakini.com/news/127990

Malaysiakini. (2010f). BN serang Zaid kerana bukan anak tempatan. Malaysiakini, April 13. Retrieved from: https://www.malaysiakini.com/news/129042

Malaysiakini. (2010g). Muhyiddin dicabar isytihar harta bersama Zaid. Malaysiakini, April 15. Retrieved from: https://www.malaysiakini.com/news/129245

Malaysiakini. (2010h). Zaid: Minum arak cerita lam. Malaysiakini, April 18. Retrieved from: https://www.malaysiakini.com/news/129532

Malaysiakini. (2010i). PAS: Semua mantan PM kecuali Pak Lah minum arak. Malaysiakini, April 20. Retrieved from: https://www.malaysiakini.com/news/129704

Malaysiakini. (2010j). SPR perjelas pemindahan pengundi Kpg Tanjung. Malaysiakini, April 19. Retrieved from: https://www.malaysiakini.com/news/129616

Malaysiakini. (2010k). Pemindahan pusat undi, Speaker tolak usul PKR. Malaysiakini, April 20. Retrieved from: https://www.malaysiakini.com/news/129682

Malaysiakini. (2010l). Kain rentang dakwa debat perdana Najib-Anwar. Malaysiakini. April 23. Retrieved from: https://www.malaysiakini.com/news/130060

Malaysiakini. (2010m). Nik Aziz dilarang berceramah di masjid Hulu Selangor. Malaysiakini, April $23 . \quad$ Retrieved from: https://www.malaysiakini.com/news/130020 
Malaysiakini. (2010n). Pakatan mula kempen di Hulu Selangor. Malaysiakini, March 27. Retrieved from: https://www.malaysiakini.com/news/127637

Malaysiakini. (2010o). Amaran' MB: BN menang, tariff air Selangor naik. Malaysiakini, April 10. Retrieved from: https://www.malaysiakini.com/news/128841

Malaysiakini. (2010p). Nik Aziz terus gempur kubu UMNO. Malaysiakini, April 24. Retrieved from: https://www.malaysiakini.com/news/130140

Malaysiakini. (2010q). Tiada kempen tapi empat sekolah baru dijanjikan. Malaysiakini, April 2. Retrieved from: https://www.malaysiakini.com/news/128198

Malaysiakini. (2010r). Hulu Selangor: Rasuah ditaburi sebelum pilihan raya. Malaysiakini, April $3 . \quad$ Retrieved from: https://www.malaysiakini.com/letters/128252

Malaysiakini. (2010s). Pemimpin AMK keluar PKR, kecewa Zaid jadi calon. Malaysiakini, April 18. Retrieved from: https://www.malaysiakini.com/news/129516

Malaysiakini. (2010t). Dr. Halili keluar PKR masuk UMNO. Malaysiakini, April 19. Retrieved from: https://www.malaysiakini.com/news/129561

Malaysiakini. (2010u). Dua pemimpin wanita PKR Perak keluar parti. Malaysiakini, April 20. Retrieved from: https://www.malaysiakini.com/news/129699

Mason, J. (2002). Qualitative Researching. London: SAGE.

McNabb, D.E. (2010). Research Methods for Political Science: Quantitative and Qualitative Approaches (2 $\left.{ }^{\text {nd }} \mathrm{Ed}\right)$. London: Routledge.

Ming, O.K. (2010). Pakatan Rakyat: What Is Different This Time? The Round Table, 99(407), 141-152.

Norris, P. (1990). By-Elections: Their Importance in Britain. Contemporary Record, 4(2), $1-2$.

Pakatan Rakyat Manifesto in Hulu Selangor By-Election. (2010).

Parliamentary Debates. (2010). Twelfth Parliament, Third Session. Kuala Lumpur: Percetakan Nasional Malaysia.

Romeo, A. (2011). Communicate Over a Network: The Blog as a New Social Space. International Review of Sociology, 21(3), 483-493.

Segall, A. \& Sandra, S. (2006). Reading the Newspaper as a Social Text. The Social Studies, 97(3), 91-99.

The Election Commission of Malaysia (2010). The Result of April 2010 Hulu Selangor ByElection. Kuala Lumpur: Percetakan Nasional Malaysia.

The Election Commission of Malaysia. (2008). The Results of the $12^{\text {th }}$ General Elections in the State of Selangor. Kuala Lumpur: Percetakan Nasional Malaysia.

Tosh, J. (2010). The Pursuit of History: Aims, Methods, and New Directions in the Study of Modern History. New York: Longman.

Waldman, M. (2004). International Newspapers and Research. The Serials Librarian, 45(4), 71-80. 